\title{
PENGARUH E-MODUL BERBASIS DISCOVERY LEARNING PADA MATA PELAJARAN SISTEM KOMPUTER TERHADAP HASIL BELAJAR SISWA KELAS X SMK NEGERI 3 SINGARAJA
}

\author{
Komang Surya Wedaswara Artha ${ }^{1}$, Ketut Agustini ${ }^{2}$, Nyoman Sugihartini ${ }^{3}$ \\ 1,2,3 Jurusan Pendidikan Teknik Informatika/Universitas Pendidikan Ganesha \\ Singaraja, Bali
}

Email: surya.weda@yahoo.com¹, ketutagustini@undiksha.ac.id ${ }^{2}$, sugihartini@undiksha.ac.id ${ }^{3}$

\begin{abstract}
Abstrak
Penelitian ini bertujuan untuk mengetahui (1) perbedaan hasil belajar antara siswa yang belajar menggunakan e-modul berbasis discovery learning dan siswa yang belajar menggunakan buku sekolah elektronik pada mata pelajaran Sistem Komputer siswa kelas X Multimedia SMK Negeri 3 Singaraja (2) respon siswa kelas X Multimedia SMK Negeri 3 Singaraja setelah menggunakan e-modul berbasis discovery learning mata pelajaran Sistem Komputer. Jenis penelitian ini adalah eksperimen semu (quasi eksperimen) dengan desain Post Test Only Control Group Design. Populasi penelitian mencakup seluruh siswa kelas X Multimedia SMK Negeri 3 Singaraja Tahun Pelajaran 2017/2018. Sampel yang digunakan yaitu kelas $\mathrm{X}$ Multimedia2 yang digunakan sebagai kelas eksperimen dan $\mathrm{X}$ Multimedia1 yang digunakan sebagai kelas kontrol, dengan jumlah 73 orang. Metode pengumpulan data yang digunakan yaitu metode tes uraian untuk mengukur hasil belajar, dan metode angket untuk menganalisis respon siswa. Data hasil belajar kemudian dianalisis dengan melakukan uji prasyarat yang meliputi uji normalitas, uji homogenitas dan uji-t. Hasil penelitian menunjukkan bahwa (1) terdapat hasil belajar yang lebih tinggi antara siswa yang belajar menggunakan e-modul berbasis discovery learning dan siswa yang belajar menggunakan media konvensional pada mata pelajaran Sistem Komputer siswa kelas X Multimedia SMK Negeri 3 Singaraja. Hasil analisis uji-t memperoleh thitung sebesar 6,5289 dan tabel sebesar 1,664 untuk dk sebesar 72 dengan taraf signifikan 5\%. Berdasarkan kriteria pengujian diperoleh thitung $>$ ttabel, ini berarti $\mathrm{HO}$ ditolak. (2) respon siswa dari penerapan E-Modul berbasis discovery learning pada mata pelajaran Sistem Komputer adalah positif dilihat dari rata - rata skor hasil angket respon siswa yaitu 93,13.
\end{abstract}

Kata kunci: Quasi Eksperimen, E-Modul, Sistem Komputer, Discovery Learning

\begin{abstract}
The purposes of this research are to know : (1) Differences in learning result between students learn using e-module based on discovery learning and students who learn using electronic school books on Computer System course of X Multimedia class at SMK Negeri 3 Singaraja. (2) the response of the 10th grade students of Multimedia in SMK Negeri 3 Singaraja after using e-module based on discovery learning in Computer System course. The type of this research is quasi-experimental research with research design Post Test Only Control Group Design. The population of this research includes all of 10th grade students of Multimedia in SMK Negeri 3 Singaraja academic year 2017/2018. The sample that used is X Multimedia 2 as an experimental class and X Multimedia 1 as a control class with total of 73 students. The data was collected using an essay test method to measure
\end{abstract}


the learning result and questionnaire method to analyzed the students responses. Data was analyzed Data was analyzed by studying the results of test preconditions including normality test, homogeneity test and t-test. The result of this research shows (1) there was higher learning result between students learn using e-module based on Discovery Learning and students who learn using conventional media on Computer System course of X Multimedia class at SMK Negeri 3 Singaraja. T-test analysis results obtained tcount $_{\text {for }}$ 6,5289 and $t_{\text {table }}$ of 1,664 for $\mathrm{dk}$ of 72 with significant values of $5 \%$. Based on criteria obtained $t_{\text {count }}>t_{t a b l e, ~ t h i s ~ m e a n s ~ t h a t ~}^{H O}$ is rejected. (2) results analysis of students responses from application e-module based on Discovery Learning on Computer System showed a positive responses with an average responses value of 93,13 .

Keywords : Quasi Eksperimen, E-Module, Computer System, Discovery Learning

\section{PENDAHULUAN}

Pendidikan merupakan usaha sadar dan terencana untuk mewujudkan suasana belajar dan proses pembelajaran agar peserta didik secara aktif mengembangkan potensi dirinya untuk memiliki kekuatan spiritual keagamaan, pengendalian diri, kecerdasan, kepribadian, ahlak mulia serta keterampilan yang diperlukan dirinya, masyarakat, bangsa dan negara. Banyak komponen - komponen yang harus dipadukan untuk menuju suatu keberhasilan pada proses pembelajaran, salah satunya adalah bahan ajar [1]. Bahan ajar sangat penting karena tanpa bahan ajar guru akan sulit meningkatkan efektivitas pembelajaran, dan siswa menjadi sulit menyesuaikan diri saat belajar. Pemilihan model pembelajaran harus disesuaikan dengan karakteristik materi pelajaran serta karakteristik siswa. Penggunaan model pembelajaran yang tepat akan dapat meningkatkan semangat belajar siswa ${ }^{[2]}$.

Saat ini sudah banyak sekolah sekolah baik dari SD, SMP, SMA /SMK yang telah menerapkan berbagai macam bahan ajar. Bahan ajar yang digunakan sudah tentu harus sesuai dengan Kurikulum yang diterapkan oleh sekolah tersebut.

SMK Negeri 3 Singaraja merupakan salah satu sekolah kejuruan yang ada di Bali, yang telah menerapkan Kurikulum 2013, sehingga SMK Negeri 3 Singaraja mampu menciptakan sumber daya manusia (SDM) yang memiliki keahlian, keterampilan, dan kemampuan yang mampu bersaing di dunia kerja setelah lulus nanti. Saat ini, SMK Negeri 3 Singaraja memiliki sepuluh kompetensi keahlian, salah satunya adalah Multimedia. Keahlian Multimedia terdapat mata pelajaran yaitu sistem komputer. Tujuan dari mata pelajaran produktif ini adalah sebagai pemahaman dasar untuk peserta didik dalam pengimplementasian proses struktur dalam komputer.

Hasil wawancara dengan guru mata pelajaran yang dilaksanakan pada tanggal 1 Maret 2017, menyatakan bahwa mata pelajaran Sistem Komputer merupakan pembelajaran baru yang menyebabkan kurangnya media pembelajaran dengan materi yang terstruktur sebagai panduan belajar siswa baik di sekolah maupun di luar sekolah. Guru menggunakan internet sebagai sumber belajar yang kemudian dibuat menjadi presentasi powerpoint.

Permasalahan lain yang terjadi yaitu keterbatasan waktu juga menjadi hambatan guru dalam menyampaikan materi pembelajaran di kelas sehingga guru kekurangan waktu dalam mengontrol pembelajaran. Dalam proses pembelajaran, metode pengajaran guru selama ini masih menggunakan metode ceramah sehingga kurang efektif, di mana pembelajaran masih berpusat pada guru sehingga kurang melibatkan partisipasi aktif siswa dalam proses pembelajaran serta menyebabkan sebagian siswa merasa bosan dan cenderung hanya sekadar mendengarkan penjelasan dari guru.

Menurut guru mata pelajaran Sistem Komputer penggunaan media ajar pada proses pembelajaran sangat berpengaruh karena dengan adanya media ajar maka akan dapat membangkitkan semangat 
belajar siswa sehingga memperoleh hasil belajar yang optimal ${ }^{[3]}$.

Baskara (2016) telah mengembangkan sebuah e-modul di SMK Negeri 3 Singaraja dengan judul "Pengembangan E-Modul Berbasis Model Pembelajaran Discovery Learning Pada Mata Pelajaran Sistem Komputer (Studi Kasus: Siswa Kelas X Multimedia SMK Negeri 3 Singaraja)". Dalam pola penelitian yang dilakukan, untuk tahap pengukuran hasil pembelajaran tidak dilakukan. Pengembangan modul hanya dilaksanakan sampai kegiatan uji coba terbatas yaitu suatu upaya untuk melakukan evaluasi dan revisi sehingga mendapatkan suatu prototypes berupa e-modul Sistem Komputer. Terkait dengan hal ini maka timbul niat untuk mengkaji lebih jauhapakah penerapan E-modul Berbasis Discovery Learning Pada Mata Pelajaran Sistem Komputer untuk Siswa Kelas X Multimedia SMK Negeri 3 Singaraja berpengaruh terhadap hasil belajar siswa dalam penelitian yang berjudul "Pengaruh EModul Berbasis Discovery Learning pada Mata Pelajaran Sistem Komputer Terhadap Hasil Belajar Siswa Kelas X Multimedia SMK Negeri 3 Singaraja".

\section{KAJIAN TEORI}

\section{A. Teori Belajar}

Belajar adalah suatu proses usaha yang dilakukan seseorang untuk memperoleh suatu perubahan tingkah laku yang baru secara keseluruhan, sebagai hasil pengalamannya sendiri dalam interaksi dengan lingkungannya [4]. Teori belajar adalah upaya untuk menggambarkan bagaimana orang dan hewan belajar, sehingga membantu kita memahami proses kompleks inheren pembelajaran [5].

Teori belajar behavioristik adalah sebuah teori yang dicetuskan oleh Gage dan Berliner tentang perubahan tingkah laku sebagai hasil dari pengalaman. Teori ini lalu berkembang menjadi aliran psikologi belajar yang berpengaruh terhadap arah pengembangan teori dan praktek pendidikan dan pembelajaran yang dikenal sebagai aliran behavioristik. Aliran ini menekankan pada terbentuknya perilaku yang tampak sebagai hasil belajar

Teori belajar Kognitivisme merupakan proses internal yang melibatkan memori, motivasi, refleksi, berfikir, dan meta kognisi. Dalam pandangan aliran tersebut, pikiran manusia memanipulasi simbol-simbol seperti komputer memanipulasi data. Karena itu, pembelajar dianggap sebagai prosesor informasi.

Teori belajar Konstruktivisme adalah teori pembelajaran yang mementingkan perubahan tingkah laku pada pelajar, contohnya dari tidak tahu kepada tahu [6].

Teori belajar Humanisme merupakan suatu teori dalam pembelajaran yang mengedepankan bagaimana memanusiakan manusia serta peserta peserta didik mampu mengembangkan potensi dirinya.

\section{B. E-Modul}

Seiring dengan perkembangan teknologi telah memungkinkan seorang pengembang pembelajaran dalam mengubah penyajian bahan ajar, dalam hal ini modul cetak, menjadi modul elektronik (e-modul). Modul elektronik menggabungkan konsep sebuah bahan ajar modul yang disampaikan melalui media elektronik. Modul elektronik merupakan sebuah bentuk penyajian bahan belajar mandiri yang disusun secara sistematis ke dalam unit pembelajaran terkecil untuk mencapai tujuan pembelajaran tertentu, yang disajikan dalam format elektronik, di mana setiap kegiatan pembelajaran di dalamnya dihubungkan dengan link-link sebagai navigasi, dilengkapi dengan penyajian video tutorial, animasi dan audio untuk memperkaya pengalaman belajar.

C. Model Pembelajaran Discovery Learning Model pembelajaran discovery learning merupakan bagian dari pembelajaran yang berpusat pada siswa. Pembelajaran yang berpusat pada siswa (Student-Centered Learning), peserta didik diharapkan sebagai peserta aktif dan mandiri dalam proses belajarnya, yang bertanggung jawab dan 
berinisiatif untuk mengenali kebutuhan belajarnya, menemukan sumber-sumber informasi untuk dapat menjawab kebutuhannya, membangun serta mempresentasikan pengetahuannya berdasarkan kebutuhan serta sumbersumber yang ditemukannya [7].

Dalam pembelajaran discovery learning ini Penemuan konsep tidak disajikan dalam bentuk akhir, tetapi peserta didik didorong untuk mengidentifikasi apa yang ingin diketahui dan dilanjutkan dengan mencari informasi sendiri kemudian mengorganisasi atau mengkonstruksi apa yang mereka ketahui dan pahami dalam suatu bentuk akhir. Sehingga menerapkan model pembelajaran discovery learning dalam proses belajar mengajar perlu diperhatikan prosedur-prosedur pelaksanaannya yang terdiri dari Stimulation, Problem Statement, Data Collection, Data Processing, Verification dan Generalization, agar penerapannya sesuai dengan tujuan yang ingin dicapai.

D. Mata Pelajaran Sistem Komputer

Sistem komputer merupakan salah satu mata pelajaran bidang keahlian TIK yang diajarkan pada kelas $X$ dan kelas $X I$ di SMKN 3 Singaraja yang wajib dikuasai, pada kelas $X$ di SMKN 3 Singaraja mata pelajaran sistem komputer diajarkan pada 2 semester yaitu semester ganjil dan genap. Mata pelajaran sistem komputer ini terbilang baru untuk SMK karena mata pelajaran ini ada semenjak diimplementasikannya kurikulum 2013 pada sekolah-sekolah di Indonesia. Tujuan siswa mempelajari mata pelajaran sistem komputer ini adalah untuk mendidik siswa memahami tentang bagaimana rancangan konstruksi sebuah komputer, Adapun beberapa materi yang diajarkan pada mata pelajaran ini diantaranya yaitu sistem bilangan, relasi logik dan fungsi gerbang dasar, operasi aritmatika, dan lain sebagainya.

E. Hasil Belajar

Hasil belajar merupakan tujuan akhir dilaksanakannya kegiatan pembelajaran di sekolah. Hasil belajar dapat ditingkatkan melalui usaha sadar yang dilakukan secara sistematis mengarah pada perubahan yang positif yang kemudian disebut dengan proses belajar.

Faktor-faktor yang mempengaruhi hasil belajar banyak jenisnya, tetapi dapat digolongkan menjadi dua jenis saja, yaitu faktor intern dan ekstern [8].

1. Faktor Intern

Faktor internal adalah faktor-faktor yang berasal dari dalam diri individu dan dapat mempengaruhi hasil belajar individu.

\section{Faktor Ekstern}

Faktor-faktor yang mempengaruhi belajar dapat digolongkan menjadi dua golongan, yaitu faktor lingkungan sosial dan faktor lingkungan non sosial.

\section{METODE}

Penelitian ini mengikuti desain penelitian quasi eksperimen dengan rancangan "posttest only control group design" di mana pada penelitian ini diberikan perlakuan yang berbeda kepada kedua kelas yaitu kelas ekperimen dengan jumlah siswa 37 orang dan kelas kontrol dengan jumlah siswa 36 . Kelas ekperimen diberikan perlakuan berupa media e-modul saat proses pembelajaran berlangsung dan kelaskontrol dengan media pembelajaran konvensional

Sebelum menentukan kelas yang akan digunakan sebagai sampel peneliti melakukan uji kesetaraan terlebih dahulu dengan menggunakan uji-t. Metode pengumpulan data yang digunakan dalam penelitian ini adalah metode tes. Metode tes digunakan untuk mengetahui hasil belajar sistem komputer siswa dengan menggunakan tes uraian dan metode angket digunakan untuk mengetahui respon siswa terkait dengan penggunaan e-modul berbasis discovery learning.

Adapun Metode dan Instrumen Pengumpulan Data yang digunakan dalam penelitian ini dapat disajikan pada Tabel 1 berikut. 
Tabel 1 Metode dan Instrumen Pengumpulan Data

\begin{tabular}{cccccc}
\hline Variabel & Sumber Data & Metode & Instrumen & Waktu & Sifat Data \\
\hline $\begin{array}{c}\text { Hasil Belajar } \\
\text { Sistem } \\
\text { Komputer }\end{array}$ & $\begin{array}{c}\text { Siswa kelompok } \\
\text { kelas eksperimen } \\
\text { dan kelas kontrol }\end{array}$ & Tes & $\begin{array}{c}\text { Tes hasil belajar } \\
\text { kognitif (tes uraian) }\end{array}$ & $\begin{array}{c}\text { Setelah Proses } \\
\text { Pembelajaran }\end{array}$ & $\begin{array}{c}\text { Skor Data } \\
\text { Interval }\end{array}$ \\
\hline Respon siswa & $\begin{array}{c}\text { Siswa kelompok } \\
\text { kelas eksperimen }\end{array}$ & Angket & Angket respon & Setelah Proses & $\begin{array}{c}\text { Skor Data } \\
\text { Ordinal }\end{array}$ \\
\hline
\end{tabular}

Perangkat pembelajaran dan instrumen penelitian dilakukan pengujian terlebih dahulu untuk mendapat gambaran secara empirik apakah perangkat dan instrumen layak digunakan dalam penelitian. Validasi perangkat pembelajaran dilakukan dengan menentukan validitas isi perangkat pembelajaran, sedangkan validiasi instrumen penelitian dilakukan dengan menentukan validitas isi tes, reliabilitas tes, indeks kesukaran butir tes dan indeks daya beda tes. Validitas tes ini ditinjau dari validitas isi dan validitas konstruk. Untuk memperoleh tujuan dari proses analisis, data terlebih dahulu dianalisis dengan menggunakan uji validitas tes dan reliabilitas tes. Rancangan validasi perangkat pembelajaran dan uji coba instrument penelitian dapat dilihat pada Tabel 2.

Tabel 2 Validasi Perangkat Pembelajaran dan Instrumen Penelitian

\begin{tabular}{|c|c|c|}
\hline $\begin{array}{c}\text { Perangkat } \\
\text { Pembelajaran dan } \\
\text { Instrumen Penelitian }\end{array}$ & Uji Coba & Dasar Estimasi \\
\hline $\begin{array}{l}\text { Rencana } \\
\text { Pelaksanaan } \\
\text { Pembelajaran (RPP) }\end{array}$ & $\begin{array}{l}\text { Validitas isi } \\
\text { (content validity) }\end{array}$ & Satu orang dosen dan satu orang guru \\
\hline \multirow{5}{*}{$\begin{array}{l}\text { Tes Posttest Sistem } \\
\text { Komputer }\end{array}$} & $\begin{array}{l}\text { Validitas isi } \\
\text { (content validity) }\end{array}$ & Satu orang dosen dan satu orang guru \\
\hline & Validitas Konstruk & $\begin{array}{l}\text { Indeks korelasi product moment antara } \\
\text { skor butir dan skor total, dengan kriteria } \\
r_{\text {hitung }}>r_{\text {tabel. }}\end{array}$ \\
\hline & Reliabilitas tes & $\begin{array}{l}\text { Koefisien Alpha Cronbach dengan } \\
\text { kriteria: } r>0.8\end{array}$ \\
\hline & $\begin{array}{l}\text { Indek Kesukaran } \\
\text { Butir (IKB) }\end{array}$ & $\begin{array}{l}\text { Formula Mehrens dan Lehmen, dengan } \\
\text { kriteria: } 0,25 \leq \mathrm{IKB} \leq 0,74\end{array}$ \\
\hline & Indeks Daya Beda & $\begin{array}{l}\text { Formula Ferguson, dengan kriteria : IDB > } \\
0,40 \text {. }\end{array}$ \\
\hline Angket Respon & $\begin{array}{l}\text { Validitas isi } \\
\text { (content validity) }\end{array}$ & Satu orang dosen dan satu orang guru \\
\hline
\end{tabular}

Data yang diperoleh dalam penelitian ini adalah data kuantitatif dan kualitatif. Data kuantitatif akan dianalisis dengan analisis statistik deskriptif untuk mendeskripsikan data hasil belajar dan respon siswa terhadap penggunaan e-modul berbasis discovery learning, kemudian data kualitatif dianalisis dengan memberi makna terhadap deskripsi data. Analisis statistik yang akan digunakan berupa uji normalitas, uji homogenitas, dan uji hipotesis. Uji normalitas dilakukan dengan menggunakan analisis Chi-Square dan uji homogenitas dilakukan dengan menggunakan uji $\mathrm{F}$, sedangkan uji hipotesis 
dilakukan untuk mengetahui apakah hipotesis alternatif yang telah diajukan diterima atau ditolak dengan menggunakan rumus polled varians. Skor rata - rata respon siswa didapatkan dengan membagi jumlah skor respon siswa dengan jumlah siswa.

\section{HASIL DAN PEMBAHASAN}

\section{Hasil Penelitian}

Berdasarkan data pengukuran hasil belajar kognitif mata pelajaran Sistem Komputer terhadap 37 siswa kelompok eksperimen, diperoleh data distribusi frekuensi skor posttest hasil belajar kognitif mata pelajaran Sistem Komputer kelompok eksperimen, skor tertinggi siswa adalah 36 dan skor terendah siswa adalah 26 dengan rentangan 10, banyak kelas interval 6 dan panjang kelas interval adalah 2. Rata-rata atau mean (M) hasil belajar Sistem Komputer yang dicapai siswa pada kelas eksperimen sebesar 32.0. Kategori skor data hasil belajar siswa kelas eksperimen dilihat pada Gambar 1.

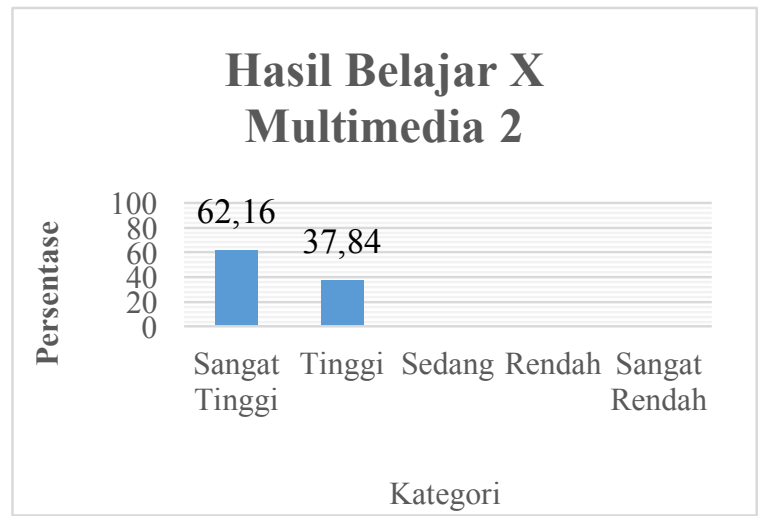

Gambar 1 Histogram Hasil Belajar Sistem Komputer Kelompok Eksperimen

Berdasarkan data pengukuran hasil belajar kognitif mata pelajaran Sistem Komputer terhadap 36 siswa kelompok kontrol, diperoleh data distribusi frekuensi skor posttest hasil belajar kognitif mata pelajaran Sistem Komputer kelompok kontrol, skor tertinggi siswa adalah 34 dan skor terendah siswa adalah 23 dengan rentangan 11, banyak kelas interval 6 dan panjang kelas interval adalah 2. Rata-rata atau mean (M) hasil belajar sistem komputer yang dicapai siswa pada kelas kontrol sebesar 27.67. Kategori skor data hasil belajar siswa kelas kontrol ditunjukkan pada Gambar 2.

\section{Hasil Belajar X Multimedia 1}

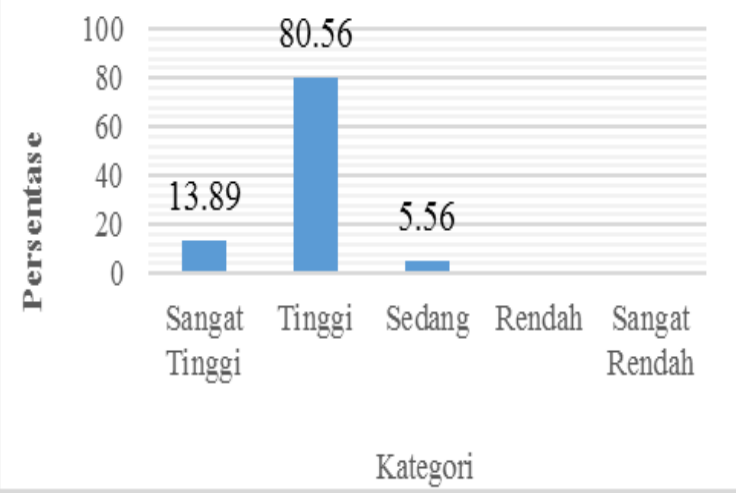

Gambar 2 Histogram Hasil Belajar Sistem Komputer Kelompok Kontrol

Perhitungan uji prasyarat dilakukan dalam dua buah uji yakni uji normalitas dan uji homogenitas. Uji normalitas data hasil belajar dilakukan dengan dua jenis perhitungan yaitu dengan menggunakan Ms. Excel 2016 dan menggunakan SPSS 23.0. Hasil belajar kelas eksperimen dengan melakukan perhitungan pada Ms. Excel 0.786 dan kelas kontrol mendapatkan hasil $\mathrm{x}^{2}$ hitung sebesar $10,346 . \mathrm{X}^{2}$ hitung dengan $\mathrm{dk}=6$ $1=5$ adalah sebesar 11,1 dengan demikian data kelas eksperimen dan kelas kontrol dinyatakan berdistribusi normal karena $\mathrm{x}^{2}$ hitung $<\mathrm{x}^{2}$ tabel yang ditunjukkan pada Tabel 3. berikut

\section{Tabel 3.Rangkuman Hasil Uji Normalitas} Ekperimen dan Kontrol

\begin{tabular}{llccc}
\hline No & Sampel & $\mathrm{X}_{\text {hitung }}^{2}$ & $\mathrm{X}_{\text {tabel }}^{2}$ & $\begin{array}{c}\text { Keterang } \\
\text { an }\end{array}$ \\
\hline 1. & $\begin{array}{l}\text { Kelompok } \\
\text { eksperimen }\end{array}$ & 0.786 & 11,1 & Normal \\
\hline
\end{tabular}




\begin{tabular}{|l|l|l|l|l|}
\hline 2. & $\begin{array}{l}\text { Kelompok } \\
\text { kontrol }\end{array}$ & 10.346 & 11,1 & Normal \\
\hline
\end{tabular}

Selain menggunakan Ms. Excel 2016, perhitungan uji normalitas juga dilakukan dengan menggunakan SPSS 23.0 dengan hasil seperti pada tabel 4 berikut

Tabel 4. Rangkuman Uji Normalitas dengan SPSS 23.0

\begin{tabular}{ccccc}
\hline Kelas & $\begin{array}{l}\text { Kolmogorov } \\
\text {-Smirnov }\end{array}$ & $\begin{array}{l}\text { Shapiro } \\
\text {-Wilk }\end{array}$ & Sig & Keterangan \\
\hline Eksperimen & 0,193 & 0,067 & 0,05 & Normal \\
\hline Kontrol & 0,102 & 0,066 & 0,05 & Normal
\end{tabular}

Dari hasil uji normalitas menggunakan SPSS 23.0 menunjukkan bahwa angka signifikan kelas eksperimen dan kelas kontrol lebih besar dari 0.05 sehinggakedua data hasil belajar tersebut dikatakan berdistribusi normal.

Perhitungan selanjutnya adalah uji homogenitas menggunakan uji $F$ sehingga mendapatkan hasil $F_{\text {hitung }}=1,058$. Derajat kebebasan (dk) untuk pembilang adalah 37 $1=36$ dan derajat kebebasan (dk) untuk penyebut adalah 36-1=35 dengan taraf signifikansi $(\alpha) 5 \%$, maka diperoleh $\mathrm{F}_{\text {tabel }}=$ 1,72. Dalam hal ini berlaku ketentuan, bila harga $F_{\text {hitung }}$ lebih kecil atau sama dengan $F_{\text {tabel }}\left(F_{\text {hitung }} \leq F_{\text {tabel }}\right)$, maka $\mathrm{HO}$ diterima dan $\mathrm{H} 1$ ditolak sehingga varians dikatakan homogen. Karena nilai $F_{\text {hitung }}<F_{\text {tabel }}(1,058<$ 1,72) maka $\mathrm{H} 0$ diterima dan $\mathrm{H} 1$ ditolak. Selain itu juga uji homogenitas dilakukan dengan SPSS 23.0 dengan hasil 0,485yang berarti homogen karena lebih besar dari taraf kesalahan yaitu 0,05.

Karena data kelas ekperimen dan kelas kontrol telah berdistribusi normal dan data homogen maka dilanjutkan dengan melakukan uji hipotesis dengan menggunakan uji-t. Uji-t dapat dihitung dengan menggunakan Ms. Excel 2017 dan SPSS 23.0. Uji-t dihitung menggunakan rumus Polled Varians memperoleh $t_{\text {hitung }}$ sebesar 6,528.

Nilai $t_{\text {tabel }}$ dengan db 73-2=71 adalah sebesar 1,664. Berdasarkan perhitungan uji$\mathrm{t}$ diperoleh $\mathrm{t}_{\text {hitung }}>\mathrm{t}_{\text {tabel }}$ yaitu $6,528>1,664$ maka H0 ditolak, berarti H1 diterima.
Berdasarkan hal ini dapat diartikan bahwa terdapat hasil belajar yang lebih tinggi antara siswa yang belajar menggunakan e-modul berbasis discovery learning dan siswa yang belajar menggunakan buku sekolah elektronik pada mata pelajaran sistem komputer siswa kelas $X$ Multimedia SMK Negeri 3 Singaraja. Uji-t juga dihitung dengan menggunakan SPSS 23.0 dengan hasil sebagai berikut:

Tabel 5. Uji Hipotesis dengan SPSS 23.0

\begin{tabular}{ccccc}
\hline & \multicolumn{3}{c}{$\begin{array}{c}\text { t-test for Equality of } \\
\text { Means }\end{array}$} \\
\cline { 3 - 5 } & $\mathbf{t}$ & $\mathbf{d f}$ & $\begin{array}{c}\text { Sig. } \\
\text { (2tailed) }\end{array}$ \\
\hline \multirow{3}{*}{ Nilai } & $\begin{array}{c}\text { Equal } \\
\text { variance } \\
\text { assumed }\end{array}$ & $\begin{array}{c}6,53 \\
6\end{array}$ & 71 & 0,000 \\
\cline { 2 - 5 } & $\begin{array}{c}\text { Equal } \\
\text { variance } \\
\text { not } \\
\text { assumed }\end{array}$ & $\begin{array}{c}6,53 \\
9\end{array}$ & $\begin{array}{c}70, \\
99\end{array}$ & 0,000 \\
\hline
\end{tabular}

Dari hasil uji-t dengan menggunakan SPSS 23.0 tersebut didapatkan nilai signifikansi sebesar 0.000 . Oleh karena nilai probabilitas siginifikan $<0.05$, maka $\mathrm{HO}$ ditolak atau $\mathrm{H} 1$ diterima. Sehingga dapat dikatakan bahwa terdapat hasil belajar yang lebih tinggi antara siswa yang belajar menggunakan e-modul berbasis discovery learning dan siswa yang belajar menggunakan buku sekolah elektronik pada mata pelajaran sistem komputer siswa kelas $X$ Multimedia SMK Negeri 3 Singaraja. 
Hasil analisis respon siswa terhadap penggunaan e-modul berbasis discovery learning pada kelas eksperimen memiliki rata-rata 93,13 dan berkategori positif dengan rincian sebanyak $37,83 \%$ berkategori sangat positif, sebanyak $51,35 \%$ berkategori positif, 10,81\% berkategori cukup positif, serta $0 \%$ siswa yang memiliki respon dalam kategori kurang positif dan sangat kurang positif. Hasil respon siswa untuk lebih jelas dapat dilihat pada Gambar 3.

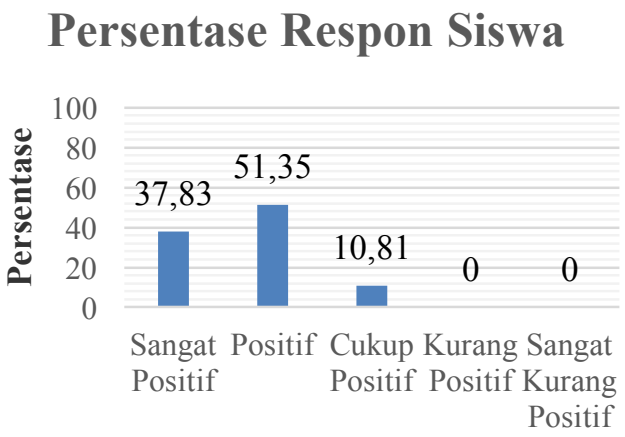

Kategori

\section{Gambar 3. Histogram Respon Siswa}

\section{Pembahasan}

Hasil belajar kelas eksperimen yang menerapkan E-modul berbasis metode pembelajaran discovery learning lebih baik, dilihat dari rata - rata skor hasil belajar siswa, yaitu rata - rata skor hasil belajar kelompok eksperimen lebih tinggi dibandingkan dengan kelompok kontrol $(32,0<27,67)$. Hal ini disebabkan karena dampak positif dari pembelajaran menggunakan e-modul.

Siswa lebih cepat mengerti dalam proses pembelajaran sistem komputer karena, e-modul berbasis discovery learning mampu mempermudah siswa dalam pencarian materi pelajaran serta mampu mengefektifkan waktu siswa untuk dapat belajar di rumah dan tidak terbatas hanya dapat belajar di sekolah saja, cara belajar siswa menjadi lebih teratur siswa langsung mendapat materi yang tersususun secara sistematis sesuai dengan indikator yang ada, dan siswa menjadi lebih mandiri dalam mengerjakan project yang diberikan [9].

Selama pelaksanaan kegiatan pembelajaran, siswa yang dibelajarkan dengan media pembelajaran e-modul terlihat lebih aktif dalam pembelajaran dibandingkan dengan siswa yang dibelajarkan dengan media pembelajaran buku sekolah elektronik. Hal ini dikarenakan siswa yang dibelajarkan dengan media pembelajaran e-modul aktif dalam mencari solusi dari permasalahan yang diberikan karena didalam e-modul terdapat fitur seperti diskusi online, fitur upload laporan, sedangkan siswa yang dibelajarkan dengan media pembelajaran buku sekolah elektronik hanya terdapat tulisan saja [10].

Siswa tidak hanya mengandalkan guru sebagai satu-satunya sumber pengetahuan tetapi siswa dapat belajar secara mandiri, terstruktur dan terarah untuk menyelesaikan tugas dan permasalahan yang diberikan. Siswa memperoleh pengalaman belajar dalam menemukan pengetahuan baru dan pemecahan masalah, siswa akan lebih memahami materi yang mereka pelajari apabila media pembelajaran yang diberikan sudah tepat [11].

Hasil analisis respon siswa terhadap penerapan e-modul berbasis discovery learning berada pada kategori positif dengan respon sebesar $51,35 \%$. Keadaan sepertiini dapat dijadikan modal untuk menciptakan suasana belajar yang efektif agar bisa meningkatkan hasil belajar siswa yang lebih tinggi. Respon positif siswa akan menjadi langkah awal untuk menuju kepada lingkungan belajar yang efektif. Jadi, dengan diperoleh respon siswa yang positif terhadap penerapan e-modul berbasis discovery learning pada mata pelajaran sistem komputer di dalam kelas dapat mengindikasikan bahwa e-modul ini dapat diterima dengan baik oleh siswa. Oleh karena itu, penerapan e-modul berbasis discovery learning pada mata pelajaran sistem komputer ini dapat dijadikan sebagai langkah alternative dalam pembelajaran di 
kelas khususnya dalam pelajaran sistem komputer.

Dalam penelitian ini adapun kendalakendala yang dihadapi peneliti saat menerapkan e-modul yang disebabkan oleh beberapa hal.

Pertama, kehadiran guru mata pelajaran sistem komputer di dalam kelas sangat singkat, sehingga tidak mengakomodasikan pelaksanaan pembelajaran secara utuh. Hal ini dapat menghambat siswa dalam penyelesaian project yang diberikan oleh guru mata pelajaran. Solusi yang dapat dilakukan untuk mengatasi kendala dalam penelitian ini adalah dengan cara peneliti mengisi ketidakhadiran guru dalam pembelajaran dan melaksanakan pembelajaran sesuai dengan rencana pelaksanaan pembelajaran yang telah disusun.

Kedua, fasilitas pembelajaran seperti laptop dan koneksi internet belum diperoleh secara maksimal, masih ada beberapa siswa yang tidak membawa laptop atau memiliki koneksi internet di setiap pertemuan dalam pembelajaran. Solusi yang dapat dilakukan peneliti dalamkendala penelitian ini adalah dengan menampilkan emodul di LCD Proyektor di depan kelas agar siswa dapat membaca maupun melihat materi dalam e-modul. Selain solusi tersebut siswa yang tidak membawa laptop diizinkan untuk menggunakan komputer sekolah dengan catatan tidak merusak fasilitas yang ada. Solusi yang dapat dilakukan untuk mengatasi kendala koneksi internet yang terbatas adalah dengan menyarankan siswa membeli voucher Wifi berbayar yang ada di sekolah.

Berdasarkan pertimbangan pertimbangan teoritik dan operasional, maka implikasi dari penelitian ini jika dilihat dari teori belajar konstruktivisme adalah proses belajar dan pembelajaran dikelas siswa harus terlibat aktif dan siswa menjadi pusat kegiatan belajar dan pembelajaran dikelas. Siswa harus dapat mengaplikasikan ide-ide mereka sendiri, siswa harus mengkonstruksikan pengetahuan dibenak mereka sendiri sehingga hasil belajar yang dicapai lebih baik. Berdasarkan hal itu bahan atau media ajar yang dapat digunakan untuk mencapai hasil belajar dengan lebih baik adalah bahan atau media ajar E-Modul Berbasis Discovery Learning Pada Mata Pelajaran Sistem Komputer.

\section{SIMPULAN}

Berdasarkan hasil penelitian dan pembahasan.Terdapat hasil belajar yang lebih tinggi antara siswa yang belajar menggunakan e-modul berbasis discovery learning dan siswa yang belajar menggunakan buku sekolah elektronik pada mata pelajaran sistem komputer siswa kelas $X$ Multimedia SMK Negeri 3 Singaraja. Dilihat rata-rata hasil belajar kelompok eksperimen dengan penerapan emodul adalah 32,0 sedangkan rata-rata posttest untuk kelompok kontrol sebesar 27,67.

Berdasarkan rata-rata hasil belajar tersebut maka dapat disimpulkan bahwa hasil belajar lebih tinggi terdapat pada siswa yang yang menggunakan emodul dan hasil dari analisis respon siswa dari penerapan emodul berbasis discovery learning pada mata pelajaran sistem komputer dilihat dari rata - rata skor respon siswa sebesar 93.13 adalah termasuk dalam kategori positif.

Dari hasil penelitian yang diperoleh maka dapat diajukan beberapa saran yaitu hasil penelitian ini menunjukkan bahwa siswa yang belajar dengan menggunakan emodul memperoleh hasil belajar yang lebih baik daripada siswa yang menggunakan media pembelajaran konvensional. Oleh karena itu, penulis menyarankan kepada guru pengajar untuk menerapkan media pembelajaran e-modul pada proses pembelajaran selanjutnya serta menyarankan bagi peneliti lain yang ingin mengembangkan media pembelajaran berupa e-modul agar membuatkan sebuah pedoman penggunaan media e-modul secara lengkap dan detail sebagai media dalam pembelajaran baik yang ditujukan kepada guru maupun kepada siswa. 


\section{REFERENSI}

[1] Agustini , K., \& Wahyuni, D. (2013). Pengaruh Penggunaan Simulasi Binary Tree Berbasis CAI Terhadap Motivasi Dan Hasil Belajar Matematika Diskrit Mahasiswa Jurusan PTI Undiksha. Jurnal Pendidikan Indonesia, 162-172.

[2] Budiningsih, C. A. (2012). Belajar \& Pembelajaran. Jakarta: PT Rineka Cipta.

[3] Candiasa, I. M. (2011). Pengujian Instrumen Penelitian Disertai Aplikasi ITEMAN dan BIGSTEPS. Singaraja: Unit Penerbitan Undiksha.

[4] Gunadharma, A. (2011). Pengembangan Modul Elektronik Sebagai Sumber Belajar Untuk Mata Kuliah Multimedia Design. Jurusan Teknologi Pendidikan, Fakultas IImu Pendidikan, Universitas Negeri Jakarta.

[5] Hariyanto. (2010, November 3). Macammacam Teori Belajar. Dipetik Maret 28, 2017 dari belajarpsikologi.com, pp.http://belajarpsikologi.com/macammacam-teori-belajar/.

[6] Pradnyana, G. A., \& Pradnyana, I. A. (2015). Implementasi Responsive Elearning Berbasis MOODLE Untuk Menunjang Kegiatan Pembelajaran di
STMIK STIKOM Indonesia. Jurnal IImu Komputer dan Sains Terapan, 127-135.

[7] Putrayasa, I. B. (2013). Landasan Pembelajaran. Singaraja-Bali: Undiksha Press.

[8] Putri, D. A. (2016). Pengaruh E-Modul Berbasis Scientific Pada Mata Pelajaran Pengolahan Citra Digital Terhadap Hasil Belajar Dan Motivasi Siswa Kelas XI Multimedia di SMK Negeri 3 Singaraja. Kumpulan Artikel Mahasiswa Pendidikan Teknik Informatika (KARMAPATI), ISSN 2252 - 9063.

[9] Sugihartini, N., Agustini, K., \& Pradnyana, G. (2017). Penerapan ELearning Di SMKN 2 Tabanan (Kajian Respon Pelatihan). Jurnal Widya Laksana, 17-23.

[10] Sugiyono. (2014). Metode Penelitian Pendidikan Pendekatan Kuantitatif, Kulitatif, dan R\&D. Bandung: Alfabeta. 